\title{
Research on the Basic Function of Market in Resources Allocation
}

\author{
Jie $\mathrm{Hao}^{1}$ \\ ${ }^{1}$ Tianjin Finance and Economics University, Tianjin, 300000
}

\section{KEYWORDS: Market, Resources Allocation, Basic Function}

\begin{abstract}
After the conversion of simple commodity economy to capitalist market economy, the market in allocating resources began to play a fundamental role. This "basic role of the market" has the historical society. In China's socialist market economy, the market also plays a fundamental role in the allocation of resources in some. However, China's socialist market economy, "the basic role of the market," not only has a capitalist market economy, "the basic role of the market" nature of the different economic base, and has advocated "universal market theory" of neo-liberalism different government policy guide and regulate the field adjustment method, which would give full play an active role in guiding the law of value, but also to avoid the negative consequences that may result from the law of value.
\end{abstract}

\section{Introduction}

After the conversion of simple commodity economy to capitalist commodity economy and capitalist market in allocating resources began to play a fundamental role. In China's socialist market economy, despite the market conditions and the role of the capitalist market economy it is different, but in the allocation of resources within a certain range in the same play a fundamental role.

A way to market is to be configured for a variety of resources for production and consumption by the law of value. In the resource allocation process, the market through the volatility of commodity prices and regulate supply and demand for commodities, thereby affecting economic behavior of commodity producers and consumers, thereby regulating the economy and development. The so-called basic role of the market refers to the allocation of resources to play a fundamental impact through the mechanism of competition, the price mechanism, supply and demand mechanism of the market mechanism.

\section{The Political Background of Market Playing a Fundamental Role in the Resources Allocation}

Congress is the turning point of the steering system of the market economy from a planned economy. Congress report: "We want to establish a socialist market economic system, it is to make the market under the socialist state macro-control allocation of resources to play a fundamental role in economic activities follow the law of value, to adapt to changes in supply and demand ; through functional leverage and price competition mechanism, the allocation of resources to better efficiency aspects go, and give enterprises the pressure and power, survival of the fittest; use a variety of market economy signal response more sensitive advantages, promote the production and demand timely coordination must also see that the market has its own weaknesses and negative aspects, we must strengthen and improve macro-control of the economy. "

Fourth Session of the Third Plenary develops the "CPC Central Committee on building a socialist market economic system on the basis of a number of issues," he reiterated the above 
formulation. The foundation said: "the establishment of a socialist market economic system is to make the national macro-control market in allocating resources play a fundamental role." Fifteenth report: "further develop the market's basic role in the allocation of resources." Congress report pointed out: "play to the basic role of the market in allocating resources to a greater extent." Third Plenum of the development of the "CPC Central Committee on perfecting the socialist market economic system on the basis of a number of issues," reiterated this formulation. Congress report: "To deepen the understanding of the socialist market economic laws, institutions to give better play to the basic role of market in allocating resources, and create favorable scientific development system of macroeconomic regulation." Eighteen report: to "play a greater and more extensive market a fundamental role in the allocation of resources." Also pointed out: "The core issue is the process of economic reform and market good government relations and it must be more respect for the laws of the market, better play the role of government."

\section{The Basic Role of the Market in the Socialist Market Economy}

In China's socialist market economy, the market allocation of resources in some still play a fundamental role, however, that "the basic role of the market" is the basic economic system of socialism with Chinese characteristics is based, and by the national macro and micro adjustment of. Basic socialist economic system with Chinese characteristics is "the basic role of the market," laid the equilibrium-oriented economic base. The cores of this system are: the public ownership is dominant and diverse forms of ownership develop. Public Economy broad sense includes both wholly-owned and collective forms of ownership also includes mutually different forms of ownership of public capital holdings and cross-shareholdings between the forms. In the economic system of socialism with Chinese characteristics, the proportion of state-owned economy to Western countries, according to the state-owned share of the economic adjustment advocated socialism with Chinese characteristics, has great practical harm, not help to improve the status of state-owned enterprises and competitiveness. Only public ownership as the main body, in order to eliminate the root causes of the economic crisis fundamentally, namely, the production and the social conflicts of capitalist private ownership of the means of production between so many areas of the national economy under the "basic role of the market," the general equilibrium the direction of sustainable development.

First, the public enterprises in market activity, by determining an appropriate ratio of accumulation and consumption and distribution according to work, to ensure that a reasonable proportion of labor remuneration in primary distribution, promotion of labor compensation growth and labor productivity increase simultaneously, thereby avoiding poor serious differentiation rich fundamentally ease the unlimited expansion of production and the ability to pay of the contradiction between demand shrinking.

Second, public enterprises and efficient for the government to adjust "the basic role of the market" to provide the necessary guarantees and financial support. With the private sector and private companies with monopoly characteristics of different anti-state regulation, public enterprises are generally willing to obey and cooperate with the state regulation. Government to iron out economic fluctuations and for "the basic role of the market," the intervention and regulation requires a lot of financial support.

Third, the public ownership economy through other ownership investment to fill the gap, to make up for "the basic role of the market," a serious shortage, promote comprehensive and balanced economic development. "The market is the basic role of an" active area of investment funds are mainly shorter recovery period, with less risk, higher-margin areas of the economy. In these areas, 
the public sector and other economic ownership can be realized fair business competition. And some of the people's livelihood is extremely important, but the recovery of funds long term, high risk, low margins, involving core national security is not suitable for other areas of ownership, can only be operated by public ownership economy.

\section{The Core Issue is to Deal with the Relationship between Government and the Market}

"Economic reform is the focus of a comprehensive deepening reform, the core issue is to deal with the relationship between government and the market, so the market play a fundamental role in the allocation of resources and better play the role of government." For the interpretation of this passage is: a comprehensive economic reform is deepening reform focus; the core issue of economic reform, through the "handle the relationship between government and the market," this way, to "make the market play a fundamental role in the allocation of resources and better play the role of government, "this goal; and how to handle the relationship between government and the market, the key is" better play the role of government."

First, the market effectively, the role of benign conditions and environment, the government needs to create and maintain. The market economy is the market play a fundamental role in the allocation of resources in the economy, but the market will not automatically play a fundamental role, or more precisely, does not automatically effective or healthy to play a fundamental role. Market effectively, the role of benign conditions and environment, the government needs to create and maintain. If the government does not function properly, or the market is difficult to play a role, or the role played by the bad rather than good effect. For example, the role of the market or a basic environmental conditions are fair and orderly market competition environment, but the environment is a prerequisite for the existence of such property to the strict, clearly defined, strict protection of property rights and enforcement of contracts to develop and implement strict protection of, and prohibitions against monopolistic practices, and so on, the Government needs to play a role. Leaving the role of government function correctly, would not achieve the basic role of the market, at least not achieve good effect.

Second, in the "market failure" in the area that requires the government to play a role. In some cases, market failure, which requires action by the government to compensate for market failure, or to create conditions for the market to play a role. From an economic perspective, the market failure is mainly manifested in seven aspects: First, the externalities, including negative externalities (such as pollution) and positive externalities (such as trees). The former will be oversupply, which would be insufficient supply. The solution is to make the cost and effectiveness of the internal. Under asymmetric information is difficult to deal fairly, there will be swindling, it is necessary for the government to solve or development agency. Seven is the total amount of macroeconomic imbalances, and so on.

Third, in the modern market economy, the government not only act as a "night watchman" passive role, but through national development strategies and planning, guidance and control of the economy. One is to reduce direct government intervention in the direction of upgrading the industrial structure. Resolve structural conflicts, and promote industrial upgrading, necessarily involves backward production capacity, exit and emerging industries, the rise of efficient enterprises inefficient enterprises, but what capacity belonging to backward production capacity, which company is inefficient enterprises, what technology, industry and enterprise more development prospects, etc., are not a government department or several officials to put Chu, have to go through market competition test. Direct government intervention, whether by asserting what capacity is backward production capacity and forced out or direct that any industry is a new 
industry and strong support, will distort market signals, reduce market efficiency, there will be serious and even diametrically opposite results. Second is to reduce direct intervention in the industrial optimization and upgrading of ways. Ways and means adopted to achieve survival of the fittest is the basis for industrial upgrading an important factor in the ability to obtain success. Backward production capacity, inefficient firms exit in what way, is being liquidated or mergers and acquisitions, in what ways mergers and acquisitions, mergers and who reorganization, etc; emerging industries, competitive enterprises to grow and develop in what way is through green field investments or mergers and acquisitions existing capacity, businesses, etc., is also very complex market selection process, not the government be able to see potential, say where, but also by the need to market competition basis. By the government-led restructuring, either take direct administrative shutdown, or "matchmaker" type of heavy merger group, whether it is restructuring state-owned enterprises, or reorganization of state-owned enterprises and private enterprises, are easily doped into many non-economic factors, not only difficult to achieve better effect restructuring, but also corruption, social instability and other remaining issues.

\section{Conclusion}

In short, the basic law of commodity economy or market economy is the law of value, the market will spontaneously play a fundamental role, but in the modern capitalist market economy has been subject to different constraints, and in the socialist market economy, China is bound to order Features basic socialist economic system as the cornerstone, it is necessary to fully play its fundamental or basic role of the market in resource allocation, but also give full play to the State in the allocation of resources should be oriented or oriented role.

\section{Reference:}

[1] Li Hui, "Invisible hand" and their relationship to each other on the two [J]. Shanghai School of Economics, 2010 (3).

[2] Cheng Enfu. Construction of new regulatory mechanisms to regulate the market as the basis for state regulation led [J]. Finance and Economics, 1990 (12).

[3] Guo Wu. Great Depression Historical Review and Reflection 1930s [J]. World Economy, 1999 (5).

[4] Stiglitz, J. E. : Markets, Market Failures, and Development [J]. The American Economic Review, 1989, Vol. 79, No. 2, pp. 197-203.

[5] Xiong Mei, Chen Li high. After the war the capitalist state intervention and reproduction cycle [J]. Nankai Economic Studies, 1989 (2).

[6] Gao Hongye. 20th century Western Micro and Macroeconomics [J]. Renmin University of China, 2000 (1).

[7] Gao Hongye, Wu Yifeng. Monetarist and supply-side [J]. Teaching Research, 1986 (6). 